DOI: $10.20472 /$ IAC.2019.052.045

\author{
PRECIOUS MNCAYI \\ North-West University, South Africa \\ PHINDILE MDLULI \\ North-West University, South Africa
}

\title{
WHY ARE THEY NOT LOOKING FOR EMPLOYMENT? A SOUTH AFRICAN YOUTH PERSPECTIVE
}

\begin{abstract}
:
It is with no doubt that unemployment, particularly among young people remains one of the most contentious issues confronting the global economy. This is not unique to South Africa as twenty-five years into democracy, unemployment remains one of the most persistent challenges with the official unemployment rate at 29 percent (one of the highest in the world) from 27.6 percent in the first quarter of 2019. The youth remain the most vulnerable with stubbornly high unemployment rates of 56.4 percent for those in the 15-24 age category and 35.6 percent for those between the ages of 25-34, and if they are working, mostly are in low quality paying and temporary employment. The fact that poverty and inequality have continued to rise, despite considerable improvements and policy strives the country has made post-apartheid, has raised questions about the country's ability to create jobs and most importantly about the factors behind the youth's reasons for not searching for employment. Using data collected through the 2019 second quarterly labour force survey by Statistics South Africa with a sample size of 4544 unemployed youth respondents, the study made use of descriptive analysis and cross tabulations to explore the South African youth's perception of the reasons why are they not looking for employment, over and above the reasons why they are unemployed. A chi-square test was used to further determine whether there are significant differences in the responses. It is believed that understanding these perceptions will perhaps provide a clear root cause to the issue which can assist with the implementation of adequate policies and may explain the effort or lack in young people's endeavours to address their situation. The findings of the study were statistically significant at the 0.01 significance level, and prove the necessity to create conditions for sustainable employment opportunities, which will be augmented by a growing economy. The findings of the study provide valuable insights within the context of South Africa as a developing country and more so, from the view point of the supply side of the youth labour market.
\end{abstract}

\section{Keywords:}

Youth work-seeker, Unemployment, Youth Labour market, South Africa

JEL Classification: E24, J21, 010 


\section{Introduction}

The global economy is faced with a challenging yet substantial socio-economic evil of escalating unemployment (International Labour Organisation (ILO), 2018). There is a general consensus that young people are among the most susceptible in the labour market (Axelrad, Malul \& Luski, 2018; Biavaschi, Eichhorst \& Giulietti, 2013) and are overrepresented in as far as unemployment is concerned (Altman, 2007). Between 1997 and 2017 a significant shrink of 34.9 million was experienced in the youth labour force universally (ILO, 2018). However, some economies have managed to maintain low unemployment levels, while others are plagued by increasing levels of general and youth unemployment, indicating the importance of public policies meant to direct the transition from school to work (Biavaschi et al., 2013). In ILO's words "There is no doubt that what young people strive for is the chance of a decent and productive job from which to build a better future ... Take away that hope and you are left with a disillusioned youth trapped in a cycle of working poverty representing a vast waste of economic potential" (ILO, 2010:2).

Unemployment applies to individuals who are without jobs, have taken time and steps to actively seek employment and are available for employment (Stats SA, 2018). By the broad definition of unemployment 6.7 million South Africans were unemployed in the second quarter of 2019, young people account for 55.2 percent of unemployed persons. This alone renders general and youth unemployment a scourge in South Africa's labour market (Stats SA, 2019). The dynamics of the country's labour market are complex for young people, who mostly struggle to find and even keep a job and are thus confronted by long-term unemployment (Graham et al., 2018). According to the National Planning Commission (2011) the persistently escalating unemployment levels pose a threat to a sustainable and inclusive economy. In South Africa, youth unemployment is a side-effect of considerably worsening levels of general unemployment, which have been fluctuating since the 1970's (Mlatsheni \& Ranchhod, 2017). However, van de Rheede (2012) alludes that the South African economy underwent a structural shift in the democratic era, which presented a noteworthy upsurge in the demand for skilled labour, subsequently presenting a challenge to unskilled labour. On the contrary, Cloet (2015) contends that South Africa's unemployment has been classified as structural in nature, both skilled and unskilled individuals are vulnerable to unemployment.

The theoretical perspective of unemployment has evolved over time (Brunner, 1978; Hall, 2003) and South Africa has implemented a number of measures and policies in a bid to reduce unemployment levels. Despite the interventions, the youth still carries the burden of unemployment and poverty, it can be argued that numerous young people in South Africa have lost hope in searching for decent and permanent jobs, some are discouraged while others face different challenges preventing them from seeking employment (Stats 
SA, 2018; Nonyana \& Njuho, 2018), the theory of job search proposes that the process of searching for a job depends on the opportunity cost of searching persistently. If an individual in search of employment is anticipating a positive response and is not incurring vast opportunity costs, then the search will be continual (Kooreman \& Ridder, 1981; Jacob, 2008). The rest of the paper is organised as follows: section 2 discusses the literature, with particular attention to youth labour market dynamics. Section 3 touches on the methodology, followed by results and discussion. The last section concludes the study and provides recommendations thereof.

\section{Contextual background}

\subsection{Youth employability and discouragement (depression)}

Unemployment, and the discouragement that stems from seeking work including several other reasons the youth is not seeking for employment is not merely a socioeconomic problem, it also embodies mental health (depression) costs and detrimental consequences (Björklund,1985; Strandh, Winefield, Nilsson \& Hammarstro 2014). There is growing evidence of the relationship between unemployment and depression (Farré, Fasani, \& Mueller, 2015; Björklund,1985; Strandh et al., 2014), literature describes depression as continual feelings of low self-esteem, worthlessness, powerlessness and in other cases suicidal thoughts (Steadman \& Taskila, 2015; Taris, 2002). Health professionals have argued that unemployment is one of the causes of depression (Furnham, 1984; de Witte, Rothmann \& Jackson, 2012; Farré et al., 2015), regardless of psychological health background (Lannoy et al., 2015). According to Björklund (1985), the shock of unemployment triggers stress and the duration of being unemployed weakens an individual's mental wellbeing leading to depression.

The expectancy-valence theory relates an individual's behaviour to their perceived outcomes, whether positive or negative. The theory deduces that the infuriation unemployed people experience when seeking employment is associated with mental-illnesses such as depression, however the impacts are severe when an individual perceives being employed as attractive since they have expectations of finding employment in the near future (Furnham, 1984). On the other hand, the latent deprivation theory is useful in explaining the experiences of the unemployed, it proposes that individuals do not only seek employment for financial gain, but there are latent functions that they gain from employment such as a daily routine, interaction with the outside world either than immediate family, establishment of own individuality and many other basic human needs (Jahoda, 1982; de Witte et al., 2012; Makiwane \& Kwizera, 2008). Deprivation of the latent functions leads to boredom and purposelessness triggering depressive episodes (Jahoda, 1982; de Witte et al., 2012; Makiwane \& Kwizera, 2008).

Chronic unemployment is an excruciating reality for South Africans, young and old especially the youth who are usually first time employment seekers. Health professionals have expressed the interlinkages between economic indicators (such as unemployment, income, wealth and so forth) and depression (Farré et al., 2015). The phase of unemployment is commonly accompanied by monetary worries, loss of income leads to change in living standards which essentially strains an individual mentally and physically (Lannoy, Graham \& Patel, 2018). Unemployed youth lack 
financial means and often feel stigmatised and deprived of valuable resources, respect and status in the society (Taris, 2002). The longer the youth is trapped in unemployment the more likely they are to fall into depression and further get discouraged from seeking employment (The South African Depression and Anxiety Group, 2019). National Planning Commission (2011) argue that youth employability and the condition of psychological depression is progressively considered a national emergency since the youth feel excluded from the labour market and the society at large, this gives birth to feelings of worthlessness (The South African Depression and Anxiety Group, 2019). The phenomenon is a rather challenging yet unique problem for the health profession and the economy at large. Strandh et al. (2014) concurs, arguing that as opposed to other reasons individuals may be not be engaged in the labour market (e.g. study leave, maternity leave etcetera), unemployment duration has undeniable adverse health consequences. Youth is a delicate time for many individuals and long-term exposure to unemployment may lead to permanent psychological depression (de Witte et al., 2012).

\subsection{Dynamics surrounding youth employability}

Age discrimination has grown to be a significant problem for younger and older employees in the labour market (Schwartz \& Kleiner, 1999; Neumark \& Stock, 1997; Taylor \& Walker, 2003; Cheung et al., 2011; Axelrad et al., 2018). Research alludes to unemployment of the youth and that of older employees, however, there are notable disparities between the two in as far as attributes, extent and solutions are concerned (Flek et al., 2017). Youth unemployment is set in motion as soon as the youth are eligible to participate in the labour force (Axelrad et al., 2018). The probability of unemployment is more prominent for the youth than it is for older individuals as first jobs are often unpredictable and short-term (Jacob, 2008). Kelly et al. (2012) expounds on the former narrative, pointing out that the youth often occupies temporary employment which is not secured, poorly compensated and in worst cases bad working conditions (Makiwane \& Kwizera, 2008). This intensifies youth vulnerability in the labour market, while acknowledging economic slumps that affect cyclically sensitive sectors.

Youth usually lacks skills and work experience that employment prospects require, as a result employment opportunities are given to more experienced individuals (Eriksson \& Dan-Olof, 2014; Axelrad et al., 2018). Eriksson and Dan-Olof (2014) assert that it is difficult for younger employees to acquire experience and relevant skills when older employees occupy key positions. The transition from schooling to employment is challenging for young people thus perpetuating long-term joblessness. Youth tend to have high expectations in as far as wage reservations, this is due to persistently increasing costs of living and high labour cost, as a result their employability is affected (Kooreman \& Ridder, 1983; Festus et al., 2016; Rankin \& Roberts, 2011). Studies (Pauw, Oosthuizen \& van der Westhuizen, 2006) argue that young people also lack interpersonal and communication skills as well as emotional intelligence. Life expectancy has increased, the retirement age has therefore increased, this implies that older and experienced individuals stay in employment longer leaving less room for new labour market entrants (Axelrad et al., 2018).

Arguably, labour market discrimination in the hiring process and over earnings is common, however age discrimination has been overlooked (Taylor \& Walker, 2003), Cheung et al. (2011) argue that age discrimination in employment is often disguised as early retirement for older employees, though used as cost cutting and effectiveness strategies in times of economic downturns. On the contrary, Caliendo and Schmidl (2015) contend that even though economic sluggishness is inevitable and has given rise to retrenchments, labour market biases contribute to the escalating level of youth unemployment since employers tend to release younger employees in an effort to reduce costs, thus avoiding laying off an experienced employee. Over and above 
labour market experience, employers find it less strenuous to lay-off the youth since employment protection laws only take effect after a certain period of employment, seemingly, employers tend to use "last in, first out" systems when retrenching. Compensation for lay-offs is higher for experienced employees who in most cases have served the company longer, retrenchments in this regard are avoided where possible (Axelrad et al., 2018). Over and above age discrimination practices in employment, an argument exists that younger people have a higher chance of being invited for an interview compared to their older counterparts, younger people are perceived as flexible, adaptable and less expectant of higher salaries (Barth, 2000). South Africa's youth labour market has an impact on supply and demand side factor of employment. Sluggish economic growth and the intensity of technological innovations dampens labour-intensive employment. This particularly affects individuals in low skilled employment. Notwithstanding the youth unemployment challenges, several young people gain access to the labour market and secure stable employment without difficulty though relatively few (Axelrad et al., 2018).

\subsection{Overview of the South African youth labour market}

South Africa's labour law rigidity is a constraint to first time employment seekers (Bernstein, 2014). The youth labour market is plagued by persistently increasing unemployment levels as one in three young people is not a labour force participant (Stats SA, 2018), while those who participate are confronted by different labour market challenges, such as low pay, poor working conditions and the like (Patel, Khan \& Englert 2018). Lack of experience and long-term unemployment remain critical drivers of youth unemployment in South Africa, however, these issues are not just unique to South Africa's labour market, they are evident in many developing countries (ILO, 2019; Biavaschi et al., 2013).

According to Patel et al. (2018) daily constraints such as living and transport expenses are among the reasons young people are unemployed and not looking for employment. Individuals at community level are unable to effectively search for employment in remote and underdeveloped areas further from the so called "economic hubs" due to financial constraints, this presents a challenge to the youth who cannot afford to buy data or visit an internet café (Mlatsheni, 2007; Smith, 2011). In the 21st century, social networks play a significant role in seeking and finding potential employment prospects, individuals with no access to these are excluded from reaching the labour market, while asymmetric information in the labour market is also alluded to as a reason for increasing youth unemployment levels (Graham et al., 2016).

In some cases, the youth is constrained from looking for employment by health issues, pregnancy being one of the reasons (Haffejee, O'Connor \& Govender, 2017). As regards historical data, South Africa's youth unemployment has a tendency of increasing in the first quarter of each year, compared to the last $\left(4^{\text {th }}\right)$ quarter of the year. It is often argued that this is a result of first time job seekers entering the labour market in the first quarter of the year (Stats SA, 2019). In the second quarter of $2019,55.2$ percent of youth aged 15 to 24 were out of jobs, graduates in this age group account for 31.0 percent of unemployment, whereas the burden of unemployment is concentrated amongst the youth (aged 15-34 years) accounting for 63.4 percent of unemployment. Higher education is still an important requirement for a successful school-to-employment in South Africa, where the probability of unemployment tends to be lower for graduates than it is for individuals with lower education levels. According to ILO (2019) youth are not able to acquire relevant skills and experience demanded by the labour market, when they are not in employment, education or training (NEET). This negatively affects their prospects of being employed and undermines economic growth and its sustainability. The gender imbalance seems to be a significant factor in the youth labour market, young females are still disadvantaged and mostly excluded from the labour market, especially those situated in rural areas and townships, since they spend most of their time running households. In the democratic era, Black youth are still the most vulnerable to 
unemployment, compared to other races, particularly White youth who are most likely to be in stable employment (Branson, De Lannoy and Brynde, 2019). Despite the challenges faced by young people in South Africa's labour market, Lannoy et al., (2018) argues that labour force participation of the youth from the supply side has increased in the country due to human capital enhancement. The next section discusses the methodology and analysis done in the study.

\section{Methodology and analysis}

\subsection{Research approach and data}

The primary objective of the study was to explore the South African youth's perception of the reasons why they are not looking for employment, over and above their employment status. A cross sectional research design was followed which then necessitated a quantitative research approach. The study used secondary data centred on the latest (2017) labour market dynamic (LMD) survey released by Statistics South Africa (Stats SA). The survey had a total of 276878 respondents across all ages (15-64) and also representative of various geography and population types. However, for the purposes of this study, the sample was limited to young people between the ages of 15 and 34 years irrespective of their employment status, totaling the sample size to 91422.

\subsection{Data analysis}

The data was analysed using IBM SPSS Statistics Version 25 software where both descriptive analysis and cross tabulations were utilised to investigate the South African youth's perception of the reasons why they are not looking for work. Furthermore, the Pearson chi-square test was utilised to determine significant differences in responses. The findings are discussed in the next section.

\section{Findings and discussions}

\subsection{Demographics}

Table 1 provides the demographic characteristics of the sample $(N=91422)$. It indicates the frequencies and percentages of the chosen demographics. Based on the results, the gender profile was objectively balanced although in favour of females $(51.1 \%)$ who were more than males (48.9\%). In as far as race is concerned, Blacks constituted the majority at 85.9 percent followed by Coloureds (8.7\%). Whites and Indians accounted for 3.7 percent and 1.8 percent respectively. Further results show that more than 80 percent of the participants were neither married nor living together with someone.

Table 1: Demographic profile of the sample

\begin{tabular}{|c|c|c|c|c|c|c|c|}
\hline Aspect & Sub-cat. & $f$ & $\%$ & Aspect & Sub-cat. & $f$ & $\%$ \\
\hline \multirow[t]{2}{*}{ Gender } & Male & 44672 & 48.9 & \multirow{3}{*}{ Marital status } & $\begin{array}{l}\text { Married / living } \\
\text { together }\end{array}$ & 16132 & 17.6 \\
\hline & Female & 46750 & 51.1 & & Not married / & 75290 & 82.4 \\
\hline \multirow{4}{*}{ Race } & Black & 78487 & 85.9 & & Living alone & $10<90$ & 02.4 \\
\hline & White & 3354 & 3.7 & \multirow{3}{*}{ Location } & Western Cape & 9341 & 10.2 \\
\hline & Asian/Indian & 1643 & 1.8 & & Eastern Cape & 10871 & 11.9 \\
\hline & Coloured & 7938 & 8.7 & & Northern & 3529 & 3.9 \\
\hline
\end{tabular}




\begin{tabular}{|c|c|c|c|c|c|c|c|}
\hline & & & & & Cape & & \\
\hline \multirow{6}{*}{$\begin{array}{l}\text { Education } \\
\text { Status }\end{array}$} & $\begin{array}{l}\text { (1)No } \\
\text { schooling }\end{array}$ & 879 & 1.0 & & Free State & 5605 & 6.1 \\
\hline & $\begin{array}{l}\text { (2)Less than } \\
\text { primary } \\
\text { completed }\end{array}$ & 3874 & 4.2 & & Kwazulu-Natal & 17079 & 18.7 \\
\hline & $\begin{array}{l}\text { (3)Primary } \\
\text { completed }\end{array}$ & 3995 & 4.4 & & North West & 5604 & 6.1 \\
\hline & $\begin{array}{l}\text { (4)Secondary } \\
\text { not completed }\end{array}$ & 47461 & 51.9 & & Gauteng & 21073 & 23.1 \\
\hline & $\begin{array}{l}\text { (5)Secondary } \\
\text { completed }\end{array}$ & 26936 & 29.5 & & Mpumalanga & 8129 & 8.9 \\
\hline & (6)Tertiary & 7568 & 8.3 & & \multirow{2}{*}{ Limpopo } & \multirow{2}{*}{10191} & \multirow{2}{*}{11.1} \\
\hline \multirow{4}{*}{$\begin{array}{l}\text { Geography } \\
\text { type }\end{array}$} & Rural & 33014 & 36.1 & & & & \\
\hline & Urban & 58408 & 63.9 & \multirow{7}{*}{$\begin{array}{l}\text { Employment } \\
\text { status }\end{array}$} & Employed & 27493 & 30.1 \\
\hline & Metro & 50834 & 55.6 & & \multirow{3}{*}{ Unemployed } & \multirow{3}{*}{18155} & \multirow{3}{*}{19.9} \\
\hline & Non-metro & 40588 & 44.4 & & & & \\
\hline \multirow{4}{*}{$\begin{array}{l}\text { Unemployment } \\
\text { status }\end{array}$} & $\begin{array}{l}\text { Job loser } \\
\text { Job leaver }\end{array}$ & $\begin{array}{l}5284 \\
984\end{array}$ & $\begin{array}{l}8.3 \\
15\end{array}$ & & & & \\
\hline & Re-entrant & 5393 & 8.4 & & $\begin{array}{l}\text { Discouraged } \\
\text { work-seeker }\end{array}$ & 6994 & 7.7 \\
\hline & New entrant & 49176 & 76.9 & & & & \\
\hline & $\begin{array}{l}\text { Last worked } \\
>5 \text { years ago }\end{array}$ & 3092 & 4.8 & & Other NEA & 38780 & 42.4 \\
\hline Long-term & $\begin{array}{l}1 \text { year and } \\
\text { longer }\end{array}$ & 11886 & 65.5 & & & & \\
\hline Unemployment & $\begin{array}{l}\text { Less than } 1 \\
\text { year }\end{array}$ & 6269 & 34.5 & & & & \\
\hline
\end{tabular}

Source: LMD survey data

If attention is placed on unemployed youth, based on the unemployment status, 76.9 percent of the participants are new labour market entrants who are first time work-seekers, re-entrants $(7.7 \%)$ who are marginally more than those who are unemployed because they have lost their jobs (8.3\%). At least 65.5 percent of the respondents have been unemployed for longer than a year. These are worrying statistics as evidence (e.g. Garcia \& Fares, 2008) shows that the longer a work-seeker remains out of the labour market, the lower their chances of finding employment, let alone a stable one. In terms of location, the results in Table 1further depict that more than 20 percent of the participants were based in Gauteng (23.1\%), KwaZulu-Natal (18.7\%), Eastern Cape $(11.9 \%)$ and Limpopo (11.1\%). In terms of geography type, most of the participants seem to be concentrated in urban locations $(63.9 \%)$ relative to those based in rural locations at 36.1 percent. Typically, Gauteng, KwaZulu-Natal and Western Cape are categorised as urban provinces due to their respective economic standing (John, 2012:55), while the remaining provinces are classified as rural (see Mncayi \& de Jongh, 2019). Metropolitan areas are home to 55.6 percent of the sample, while the remaining 44.4 percent are situated in non-metropolitan areas.

Young people struggle to complete matric and a large proportion halt their formal education here. The distribution in accordance with education status show that a large contingent $(51.9 \%)$ of young people in the sample have not yet completed secondary education relative to those that did 
at 29.5 percent. Only 8.3 percent had completed their tertiary education, and this according to Branson et al. (2019) limits employment and earning prospects, where evidence (Moleke, 2010; Van Broekhuizen, 2016; Green \& Henseke, 2016) shows that tertiary education holders enjoy better employment outcomes than their secondary and primary school counterparts. In terms of employment status, approximately 20 percent of the participants are unemployed (19.9\%). An estimated 7.7 percent are discouraged work-seekers.

In accordance with elucidating on youth's reasons pertaining to their lack of employment search. Table 2 shows that many young people have stopped looking for work mainly as a result of a lack of jobs. In addition, reasons which raise concerns include the unavailability of employment and the lack of financial resources to aid with employment search as they are a reflection of more structural socio-economic problems. This is not surprising since South Africa's economy has failed to create the much needed employment as a result of a weak economy that has been on stagnation for many years (SAIRR, 2016), with growth rates less than 3 percent seen as the new norm (Mathe, 2019).

Table 2: Reasons why the unemployed youth are not looking for employment

\begin{tabular}{|l|l|l|}
\hline Reason & $\boldsymbol{f}$ & $\%$ \\
\hline Waiting to be called back & 168 & .2 \\
\hline Health reasons & 198 & .2 \\
\hline Undergoing training to find work & 65 & .1 \\
\hline No work available in area & 6502 & 7.1 \\
\hline Lack of transport money to look for work & 653 & .7 \\
\hline Cannot find work requiring acquired skills/education & 216 & .2 \\
\hline Lost hope of finding work & 278 & .3 \\
\hline Family considerations/taking care of family & 608 & .7 \\
\hline Other reasons for not searching & 82734 & 90.5 \\
\hline \hline & 91422 & 100.0 \\
\hline \hline
\end{tabular}

Source: LMD Survey data

The economic environment has worsened even further, largely as a result of a fragile political climate, reduced global commodity demand, subdued foreign and private investment and heightened consumer vulnerability (Kumo, Chulu \& Minsat, 2016). This has lowered the demand for young workers which is fuelled by their lack of work experience. According to Dolado (2015) and Oluwajodu et al. (2015) the labour market is characterised by a tendency to employ mature workers who are perceived as more experiences, leaving the youth last in the queue struggling to accumulate experience, resulting in long unemployment spells. Many of those who do find employment are employed only for a short time before becoming unemployed yet again.

Additionally, another reason for not looking for work relates to the absence of financial resources needed to assist with employment search. This could be related to geographical difficulties where most youth are situated in rural areas mostly known to be secluded from economic and employment activity (de Jongh, 2017). Different to mature adults, young people do not have adequate resources to overcome these spatial barriers and enhance flexibility to access labour markets (Mlatsheni, 2014). Another reason for not looking for work is because of family considerations, while others have also lost any hope of finding work. Further analysis is done 
using cross tabulations on the youth's reason for not looking for work and other socio-economic variables. The findings are discussed in the next subsection.

\subsection{Cross tabulation analysis}

Table 3 presents an image on the youth's reasons for not searching for employment in terms of racial group. Of those that did not look for employment because of a lack of financial resources, more than 95 percent were blacks relative to other races. Furthermore, young blacks also constitute majority of those that have lost any hope of finding employment $(89.9 \%)$ compared to their coloured $(8.6 \%)$, Indian $(0.7 \%)$ and White $(0.7 \%)$ counterparts. Blacks as a group struggle the most in the labour market and are most likely to encounter negative labour market outcomes, and this according to Van Aardt (2012) this characteristic also holds for the younger generations, but to a greater degree. Within those that were not looking for work because the education qualifications they have is irrelevant to the needs of the labour market, 89.4 percent are black, followed by coloureds at 5.6 percent. The Pearson $\chi^{2}$ testreported in Table 3 confirms the differences in the reasons for not looking for work between the various racial groups in the data. A p-value of .000 means that we reject the null hypothesis of no significant difference between the racial categories in terms of the reasons, and conclude that there is a significant difference in the perceptions between blacks, coloureds, Indians and white youth. Generally low investments in the education black people receive, which still persist today, have inevitably implied that young blacks enter labour markets with low skill sets (Zoch, 2015). White youth are still most likely to have better education, find work most easily and therefore improved employment and earning prospects (Ingle \& Mlatsheni, 2017).

Table 3: Reasons for not looking for work and Race

\begin{tabular}{|c|c|c|c|c|c|c|c|c|}
\hline & \multicolumn{4}{|c|}{ Population group } & \multirow[b]{2}{*}{ Total } & \multirow{19}{*}{$\begin{array}{c}\text { Pearson } \\
\chi^{2} \\
\text { (Sig.) }\end{array}$} \\
\hline & & & Black & Coloured & $\begin{array}{l}\text { Indian/ } \\
\text { Asian }\end{array}$ & White & & \\
\hline \multirow{17}{*}{ Reasons } & \multirow{4}{*}{$\begin{array}{l}\text { Waiting to be } \\
\text { called back } \\
\text { at work }\end{array}$} & Count & 106 & 60 & 0 & 2 & 168 & \\
\hline & & $\%$ within new reasons & $63.1 \%$ & $35.7 \%$ & $0.0 \%$ & $1.2 \%$ & $100.0 \%$ & \\
\hline & & $\begin{array}{l}\text { \% within Population } \\
\text { group }\end{array}$ & $0.1 \%$ & $0.8 \%$ & $0.0 \%$ & $0.1 \%$ & $0.2 \%$ & \\
\hline & & $\%$ of Total & $0.1 \%$ & $0.1 \%$ & $0.0 \%$ & $0.0 \%$ & $0.2 \%$ & \\
\hline & \multirow{4}{*}{$\begin{array}{l}\text { Health } \\
\text { reasons }\end{array}$} & Count & 172 & 23 & 2 & 1 & 198 & \\
\hline & & $\%$ within new reasons & $86.9 \%$ & $11.6 \%$ & $1.0 \%$ & $0.5 \%$ & $100.0 \%$ & \\
\hline & & $\begin{array}{l}\text { \% within Population } \\
\text { group }\end{array}$ & $0.2 \%$ & $0.3 \%$ & $0.1 \%$ & $0.0 \%$ & $0.2 \%$ & \\
\hline & & $\%$ of Total & $0.2 \%$ & $0.0 \%$ & $0.0 \%$ & $0.0 \%$ & $0.2 \%$ & \\
\hline & \multirow{4}{*}{$\begin{array}{l}\text { Undergoing } \\
\text { training to } \\
\text { find work }\end{array}$} & Count & 55 & 10 & 0 & 0 & 65 & \\
\hline & & \% within new reasons & $84.6 \%$ & $15.4 \%$ & $0.0 \%$ & $0.0 \%$ & $100.0 \%$ & \\
\hline & & $\begin{array}{l}\text { \% within Population } \\
\text { group }\end{array}$ & $0.1 \%$ & $0.1 \%$ & $0.0 \%$ & $0.0 \%$ & $0.1 \%$ & \\
\hline & & $\%$ of Total & $0.1 \%$ & $0.0 \%$ & $0.0 \%$ & $0.0 \%$ & $0.1 \%$ & \\
\hline & \multirow{4}{*}{$\begin{array}{l}\text { No work } \\
\text { available in } \\
\text { area }\end{array}$} & Count & 6077 & 348 & 48 & 29 & 6502 & \\
\hline & & $\%$ within new reasons & $93.5 \%$ & $5.4 \%$ & $0.7 \%$ & $0.4 \%$ & $100.0 \%$ & \\
\hline & & $\begin{array}{l}\text { \% within Population } \\
\text { group }\end{array}$ & $7.7 \%$ & $4.4 \%$ & $2.9 \%$ & $0.9 \%$ & $7.1 \%$ & \\
\hline & & $\%$ of Total & $6.6 \%$ & $0.4 \%$ & $0.1 \%$ & $0.0 \%$ & $7.1 \%$ & \\
\hline & Lack of & Count & 626 & 25 & 1 & 1 & 653 & \\
\hline
\end{tabular}




\begin{tabular}{|c|c|c|c|c|c|c|}
\hline \multirow{3}{*}{\begin{tabular}{|l|} 
transport \\
money to \\
look for work
\end{tabular}} & $\%$ within new reasons & $95.9 \%$ & $3.8 \%$ & $0.2 \%$ & $0.2 \%$ & $100.0 \%$ \\
\hline & $\begin{array}{l}\text { \% within Population } \\
\text { group }\end{array}$ & $0.8 \%$ & $0.3 \%$ & $0.1 \%$ & $0.0 \%$ & $0.7 \%$ \\
\hline & $\%$ of Total & $0.7 \%$ & $0.0 \%$ & $0.0 \%$ & $0.0 \%$ & $0.7 \%$ \\
\hline \multirow{4}{*}{$\begin{array}{l}\text { Cannot find } \\
\text { work } \\
\text { requiring } \\
\text { acquired } \\
\text { skills and } \\
\text { education } \\
\end{array}$} & Count & 193 & 12 & 7 & 4 & 216 \\
\hline & $\%$ within new reasons & $89.4 \%$ & $5.6 \%$ & $3.2 \%$ & $1.9 \%$ & $100.0 \%$ \\
\hline & $\begin{array}{l}\text { \% within Population } \\
\text { group }\end{array}$ & $0.2 \%$ & $0.2 \%$ & $0.4 \%$ & $0.1 \%$ & $0.2 \%$ \\
\hline & $\%$ of Total & $0.2 \%$ & $0.0 \%$ & $0.0 \%$ & $0.0 \%$ & $0.2 \%$ \\
\hline \multirow{4}{*}{$\begin{array}{l}\text { Lost hope of } \\
\text { finding work }\end{array}$} & Count & 250 & 24 & 2 & 2 & 278 \\
\hline & $\%$ within new reasons & $89.9 \%$ & $8.6 \%$ & $0.7 \%$ & $0.7 \%$ & $100.0 \%$ \\
\hline & $\begin{array}{l}\text { \% within Population } \\
\text { group }\end{array}$ & $0.3 \%$ & $0.3 \%$ & $0.1 \%$ & $0.1 \%$ & $0.3 \%$ \\
\hline & $\%$ of Total & $0.3 \%$ & $0.0 \%$ & $0.0 \%$ & $0.0 \%$ & $0.3 \%$ \\
\hline \multirow{4}{*}{$\begin{array}{l}\text { Family } \\
\text { consideratio } \\
\text { ns/taking } \\
\text { care of family }\end{array}$} & Count & 562 & 36 & 5 & 5 & 608 \\
\hline & $\%$ within new reasons & $92.4 \%$ & $5.9 \%$ & $0.8 \%$ & $0.8 \%$ & $100.0 \%$ \\
\hline & $\begin{array}{l}\text { \% within Population } \\
\text { group }\end{array}$ & $0.7 \%$ & $0.5 \%$ & $0.3 \%$ & $0.1 \%$ & $0.7 \%$ \\
\hline & $\%$ of Total & $0.6 \%$ & $0.0 \%$ & $0.0 \%$ & $0.0 \%$ & $0.7 \%$ \\
\hline \multirow{4}{*}{ Other } & Count & 70446 & 7400 & 1578 & 3310 & 82734 \\
\hline & $\%$ within new reasons & $85.1 \%$ & $8.9 \%$ & $1.9 \%$ & $4.0 \%$ & $100.0 \%$ \\
\hline & $\begin{array}{l}\text { \% within Population } \\
\text { group }\end{array}$ & $89.8 \%$ & $93.2 \%$ & $96.0 \%$ & $98.7 \%$ & $90.5 \%$ \\
\hline & $\%$ of Total & $77.1 \%$ & $8.1 \%$ & $1.7 \%$ & $3.6 \%$ & $90.5 \%$ \\
\hline \multirow{4}{*}{ Total } & Count & 78487 & 7938 & 1643 & 3354 & 91422 \\
\hline & $\%$ within new reasons & $85.9 \%$ & $8.7 \%$ & $1.8 \%$ & $3.7 \%$ & $100.0 \%$ \\
\hline & $\begin{array}{l}\text { \% within Population } \\
\text { group }\end{array}$ & $100.0 \%$ & $100.0 \%$ & $100.0 \%$ & $100.0 \%$ & $100.0 \%$ \\
\hline & $\%$ of Total & $85.9 \%$ & $8.7 \%$ & $1.8 \%$ & $3.7 \%$ & $100.0 \%$ \\
\hline
\end{tabular}

Note: * denotes 0.01 level of significance, ${ }^{* *} 0.05$ level of significance

Source: LMF survey data

The gender facet in the explanation of a lack of employment search as indicated in Table 4 signals that young females are confronted with even greater obstacles in getting into the labour market than young males in South Africa (Orr \& Van Meelis, 2014). Between the two genders, of those that were not looking for employment as a result of family considerations, 96.5 percent were young females relative to their male counterparts (3.5\%). Traditionally, women face cultural barriers that have always prevented them from actively participating in the labour market. The role of women as home carers has meant that their desires must be sacrificed, hampering their income generation abilities (de Jongh, Mncayi \& Mdluli, 2019). A growing number of women encounter negative labour market outcomes (Ingle \& Mlatsheni, 2017).

Table 4: Reasons for not looking for work and Gender

\begin{tabular}{|c|c|c|c|c|c|}
\hline & \multicolumn{2}{|c|}{ Gender } & \multirow{2}{*}{ Total } \\
\hline & & & Male & Female & \\
\hline \multirow{4}{*}{ Reasons } & \multirow{4}{*}{$\begin{array}{l}\text { Waiting to be called back } \\
\text { at work }\end{array}$} & Count & 69 & 99 & 168 \\
\hline & & $\%$ within new reasons & $41.1 \%$ & $58.9 \%$ & $100.0 \%$ \\
\hline & & \% within Gender & $0.2 \%$ & $0.2 \%$ & $0.2 \%$ \\
\hline & & $\%$ of Total & $0.1 \%$ & $0.1 \%$ & $0.2 \%$ \\
\hline
\end{tabular}




\begin{tabular}{|c|c|c|c|c|c|}
\hline \multirow[t]{4}{*}{ Health reasons } & Count & 68 & 130 & 198 & \multirow{36}{*}{$\begin{array}{c}\text { Pearson } \\
\chi^{2} \\
\text { (Sig.) } \\
617.301 \\
\left(.000^{\star}\right)\end{array}$} \\
\hline & \% within new reasons & $34.3 \%$ & $65.7 \%$ & $100.0 \%$ & \\
\hline & $\%$ within Gender & $0.2 \%$ & $0.3 \%$ & $0.2 \%$ & \\
\hline & $\%$ of Total & $0.1 \%$ & $0.1 \%$ & $0.2 \%$ & \\
\hline \multirow{4}{*}{$\begin{array}{l}\text { Undergoing training to find } \\
\text { work }\end{array}$} & Count & 29 & 36 & 65 & \\
\hline & $\%$ within new reasons & $44.6 \%$ & $55.4 \%$ & $100.0 \%$ & \\
\hline & $\%$ within Gender & $0.1 \%$ & $0.1 \%$ & $0.1 \%$ & \\
\hline & $\%$ of Total & $0.0 \%$ & $0.0 \%$ & $0.1 \%$ & \\
\hline \multirow[t]{4}{*}{ No work available in area } & Count & 2881 & 3621 & 6502 & \\
\hline & $\%$ within new reasons & $44.3 \%$ & $55.7 \%$ & $100.0 \%$ & \\
\hline & \% within Gender & $6.4 \%$ & $7.7 \%$ & $7.1 \%$ & \\
\hline & $\%$ of Total & $3.2 \%$ & $4.0 \%$ & $7.1 \%$ & \\
\hline \multirow{4}{*}{$\begin{array}{l}\text { Lack of transport money to } \\
\text { look for work }\end{array}$} & Count & 268 & 385 & 653 & \\
\hline & \% within new reasons & $41.0 \%$ & $59.0 \%$ & $100.0 \%$ & \\
\hline & \% within Gender & $0.6 \%$ & $0.8 \%$ & $0.7 \%$ & \\
\hline & $\%$ of Total & $0.3 \%$ & $0.4 \%$ & $0.7 \%$ & \\
\hline \multirow{4}{*}{$\begin{array}{l}\text { Cannot find work requiring } \\
\text { acquired skills and } \\
\text { education }\end{array}$} & Count & 106 & 110 & 216 & \\
\hline & $\%$ within new reasons & $49.1 \%$ & $50.9 \%$ & $100.0 \%$ & \\
\hline & $\%$ within Gender & $0.2 \%$ & $0.2 \%$ & $0.2 \%$ & \\
\hline & $\%$ of Total & $0.1 \%$ & $0.1 \%$ & $0.2 \%$ & \\
\hline \multirow[t]{4}{*}{ Lost hope of finding work } & Count & 124 & 154 & 278 & \\
\hline & $\%$ within new reasons & $44.6 \%$ & $55.4 \%$ & $100.0 \%$ & \\
\hline & $\%$ within Gender & $0.3 \%$ & $0.3 \%$ & $0.3 \%$ & \\
\hline & $\%$ of Total & $0.1 \%$ & $0.2 \%$ & $0.3 \%$ & \\
\hline \multirow{4}{*}{$\begin{array}{l}\text { Family } \\
\text { considerations/taking care } \\
\text { of family }\end{array}$} & Count & 21 & 587 & 608 & \\
\hline & \% within new reasons & $3.5 \%$ & $96.5 \%$ & $100.0 \%$ & \\
\hline & \% within Gender & $0.0 \%$ & $1.3 \%$ & $0.7 \%$ & \\
\hline & $\%$ of Total & $0.0 \%$ & $0.6 \%$ & $0.7 \%$ & \\
\hline \multirow[t]{4}{*}{ Other } & Count & 41106 & 41628 & 82734 & \\
\hline & $\%$ within new reasons & $49.7 \%$ & $50.3 \%$ & $100.0 \%$ & \\
\hline & $\%$ within Gender & $92.0 \%$ & $89.0 \%$ & $90.5 \%$ & \\
\hline & $\%$ of Total & $45.0 \%$ & $45.5 \%$ & $90.5 \%$ & \\
\hline \multirow{4}{*}{ Total } & Count & 44672 & 46750 & 91422 & \\
\hline & $\%$ within new reasons & $48.9 \%$ & $51.1 \%$ & $100.0 \%$ & \\
\hline & \% within Gender & $100.0 \%$ & $100.0 \%$ & $100.0 \%$ & \\
\hline & $\%$ of Total & $48.9 \%$ & $51.1 \%$ & $100.0 \%$ & \\
\hline
\end{tabular}

Note: * denotes 0.01 level of significance, ${ }^{* *} 0.05$ level of significance

Source: LMF survey data

In terms of Table 5, the education status categories were numbered (see Table 1). Majority of respondents that were not searching for employment of a mismatch between their education and available work have not completed their secondary schooling $(37.5 \%)$, followed by those that have tertiary education (25.5\%) and those who have completed their secondary schooling (23.1\%). Over the years, there has been an increase in the number of students graduating in generic courses (i.e. those that do not directly prepare one for a profession) (e.g. DHET, 2019) which has becoming a problem since the number of jobs available in these fields are outweighed by the number of graduates in the field (Mncayi \& Dunga, 2016). The former courses have higher unemployment rates and longer spells of unemployment (Adcorp, 2014; Altbeker \& Storme, 2013, Van Broekhuizen, 2016). From Table 5, a large number of respondents in the $4^{\text {th }}$ and $5^{\text {th }}$ education status seems to identify the most with the indicated reasons including not searching for employment because they feel there are no job in their areas, have lost hope of finding 
employment. A large number of young people that are discouraged job-seekers are in the lower education status, i.e. secondary and primary schooling, suggesting that demand in the youth labour market has shifted towards high skills, implying that those without any higher education qualification would struggle being absorbed by the labour market (Mlatsheni, 2014). South Africa's economy has also been creating employment that is highly concentrated to the tertiary sector, typically requiring higher skills levels than those of the average work seeker (De Lannoy et al., 2018). Other contributing factors include the country's poor education system (Spaull, 2013).

Table 5: Reasons for not looking for work and Education status

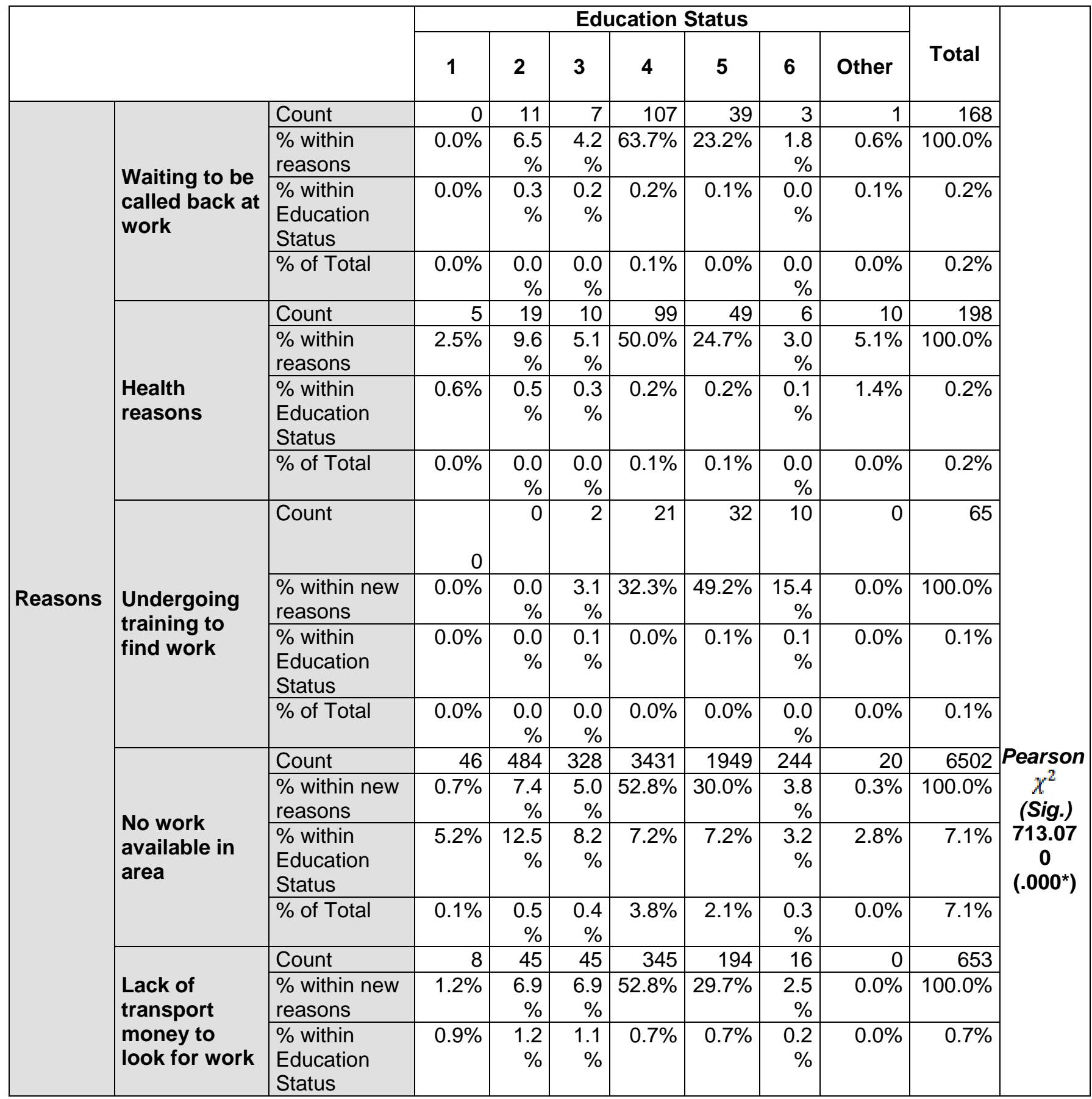




\begin{tabular}{|c|c|c|c|c|c|c|c|c|c|}
\hline & $\%$ of Total & $0.0 \%$ & $\begin{array}{r}0.0 \\
\%\end{array}$ & $\begin{array}{r}0.0 \\
\% \\
\end{array}$ & $0.4 \%$ & $0.2 \%$ & $\begin{array}{r}0.0 \\
\% \\
\end{array}$ & $0.0 \%$ & $0.7 \%$ \\
\hline \multirow{4}{*}{$\begin{array}{l}\text { Cannot find } \\
\text { work } \\
\text { requiring } \\
\text { acquired } \\
\text { skills and } \\
\text { education }\end{array}$} & \begin{tabular}{|l|} 
Count \\
\end{tabular} & 0 & 12 & 11 & 81 & 50 & 55 & 7 & 216 \\
\hline & $\begin{array}{l}\text { \% within new } \\
\text { reasons }\end{array}$ & $0.0 \%$ & $\begin{array}{r}5.6 \\
\%\end{array}$ & $\begin{array}{r}5.1 \\
\%\end{array}$ & $37.5 \%$ & $23.1 \%$ & $\begin{array}{r}25.5 \\
\%\end{array}$ & $3.2 \%$ & $100.0 \%$ \\
\hline & $\begin{array}{l}\text { \% within } \\
\text { Education } \\
\text { Status }\end{array}$ & $0.0 \%$ & $\begin{array}{r}0.3 \\
\%\end{array}$ & $\begin{array}{r}0.3 \\
\%\end{array}$ & $0.2 \%$ & $0.2 \%$ & $\begin{array}{r}0.7 \\
\%\end{array}$ & $1.0 \%$ & $0.2 \%$ \\
\hline & $\%$ of Total & $0.0 \%$ & $\begin{array}{r}0.0 \\
\%\end{array}$ & $\begin{array}{r}0.0 \\
\%\end{array}$ & $0.1 \%$ & $0.1 \%$ & $\begin{array}{r}0.1 \\
\%\end{array}$ & $0.0 \%$ & $0.2 \%$ \\
\hline \multirow{4}{*}{$\begin{array}{l}\text { Lost hope of } \\
\text { finding work }\end{array}$} & Count & 2 & 12 & 18 & 143 & 88 & 12 & 3 & 278 \\
\hline & $\begin{array}{l}\text { \% within new } \\
\text { reasons }\end{array}$ & $0.7 \%$ & $\begin{array}{r}4.3 \\
\%\end{array}$ & $\begin{array}{r}6.5 \\
\%\end{array}$ & $51.4 \%$ & $31.7 \%$ & $\begin{array}{r}4.3 \\
\%\end{array}$ & $1.1 \%$ & $100.0 \%$ \\
\hline & $\begin{array}{l}\% \text { within } \\
\text { Education } \\
\text { Status }\end{array}$ & $0.2 \%$ & $\begin{array}{r}0.3 \\
\%\end{array}$ & $\begin{array}{r}0.5 \\
\%\end{array}$ & $0.3 \%$ & $0.3 \%$ & $\begin{array}{r}0.2 \\
\%\end{array}$ & $0.4 \%$ & $0.3 \%$ \\
\hline & $\%$ of Total & $0.0 \%$ & $\begin{array}{r}0.0 \\
\% \\
\end{array}$ & $\begin{array}{r}0.0 \\
\% \\
\end{array}$ & $0.2 \%$ & $0.1 \%$ & $\begin{array}{r}0.0 \\
\% \\
\end{array}$ & $0.0 \%$ & $0.3 \%$ \\
\hline \multirow{4}{*}{$\begin{array}{l}\text { Family } \\
\text { consideration } \\
\text { s/taking care } \\
\text { of family }\end{array}$} & \begin{tabular}{|l|} 
Count \\
\end{tabular} & 10 & 28 & 25 & 374 & 150 & 17 & 4 & 608 \\
\hline & $\begin{array}{l}\% \text { within new } \\
\text { reasons }\end{array}$ & $1.6 \%$ & $\begin{array}{r}4.6 \\
\% \\
\end{array}$ & $\begin{array}{r}4.1 \\
\%\end{array}$ & $61.5 \%$ & $24.7 \%$ & $\begin{array}{r}2.8 \\
\% \\
\end{array}$ & $0.7 \%$ & $100.0 \%$ \\
\hline & $\begin{array}{l}\% \text { within } \\
\text { Education } \\
\text { Status } \\
\end{array}$ & $1.1 \%$ & $\begin{array}{r}0.7 \\
\%\end{array}$ & $\begin{array}{r}0.6 \\
\%\end{array}$ & $0.8 \%$ & $0.6 \%$ & $\begin{array}{r}0.2 \\
\%\end{array}$ & $0.6 \%$ & $0.7 \%$ \\
\hline & $\%$ of Total & $0.0 \%$ & $\begin{array}{r}0.0 \\
\% \\
\end{array}$ & $\begin{array}{r}0.0 \\
\%\end{array}$ & $0.4 \%$ & $0.2 \%$ & $\begin{array}{r}0.0 \\
\% \\
\end{array}$ & $0.0 \%$ & $0.7 \%$ \\
\hline \multirow{4}{*}{ Other } & Count & 808 & $\begin{array}{r}326 \\
3 \\
\end{array}$ & $\begin{array}{r}354 \\
9 \\
\end{array}$ & 42860 & 24385 & $\begin{array}{r}720 \\
5 \\
\end{array}$ & 664 & 82734 \\
\hline & $\begin{array}{l}\% \text { within new } \\
\text { reasons }\end{array}$ & $1.0 \%$ & $\begin{array}{r}3.9 \\
\%\end{array}$ & $\begin{array}{r}4.3 \\
\%\end{array}$ & $51.8 \%$ & $29.5 \%$ & $\begin{array}{r}8.7 \\
\%\end{array}$ & $0.8 \%$ & $100.0 \%$ \\
\hline & $\begin{array}{l}\% \text { within } \\
\text { Education } \\
\text { Status } \\
\end{array}$ & $91.9 \%$ & $\begin{array}{r}84.2 \\
\%\end{array}$ & $\begin{array}{r}88.8 \\
\%\end{array}$ & $90.3 \%$ & $90.5 \%$ & $\begin{array}{r}95.2 \\
\%\end{array}$ & $93.7 \%$ & $90.5 \%$ \\
\hline & $\%$ of Total & $0.9 \%$ & $\begin{array}{r}3.6 \\
\%\end{array}$ & $\begin{array}{r}3.9 \\
\%\end{array}$ & $46.9 \%$ & $26.7 \%$ & $\begin{array}{r}7.9 \\
\%\end{array}$ & $0.7 \%$ & $90.5 \%$ \\
\hline \multirow{4}{*}{ Total } & Count & 879 & $\begin{array}{r}387 \\
4 \\
\end{array}$ & $\begin{array}{r}399 \\
5 \\
\end{array}$ & 47461 & 26936 & $\begin{array}{r}756 \\
8 \\
\end{array}$ & 709 & 91422 \\
\hline & $\begin{array}{l}\text { \% within new } \\
\text { reasons }\end{array}$ & $1.0 \%$ & $\begin{array}{r}4.2 \\
\% \\
\end{array}$ & $\begin{array}{r}4.4 \\
\% \\
\end{array}$ & $51.9 \%$ & $29.5 \%$ & $\begin{array}{r}8.3 \\
\% \\
\end{array}$ & $0.8 \%$ & $100.0 \%$ \\
\hline & $\begin{array}{l}\% \text { within } \\
\text { Education } \\
\text { Status }\end{array}$ & $\begin{array}{r}100.0 \\
\%\end{array}$ & $\begin{array}{r}100 . \\
0 \%\end{array}$ & $\begin{array}{r}100 . \\
0 \%\end{array}$ & $\begin{array}{r}100.0 \\
\%\end{array}$ & $\begin{array}{r}100.0 \\
\%\end{array}$ & $\begin{array}{r}100 . \\
0 \%\end{array}$ & $100.0 \%$ & $100.0 \%$ \\
\hline & $\%$ of Total & $1.0 \%$ & $\begin{array}{r}4.2 \\
\%\end{array}$ & $\begin{array}{r}4.4 \\
\%\end{array}$ & $51.9 \%$ & $29.5 \%$ & $\begin{array}{r}8.3 \\
\%\end{array}$ & $0.8 \%$ & $100.0 \%$ \\
\hline
\end{tabular}

Note: * denotes 0.01 level of significance, ${ }^{* *} 0.05$ level of significance

Source: LMF survey data

In terms of provincial location, most youth that stopped looking for work because of the unavailability of work in their areas were from rural provinces $(61.6 \%)$ in contrast to 38.4 percent based in urban provinces (see Table 6). These findings are also echoed by further analysis (not shown) with regards to geographical location which show that 60.1 percent of the respondents who identified with that reason were from non-metropolitan areas relative to 39.9 percent from 
metropolitan areas ${ }^{1}$. According to Fischer and Siddiq (2013) the main difference between a metro-area and a non-metro is the strong commuting links to a large urbanised centre a metroarea has compared to a non-metro. Weingarden (2017) identified growing disparities between metro and non-metro areas in the US. The study found that over and above the low educational rates, those from non-metro areas are more likely to be unemployed or out of the labour force compared to their metro counterparts. In South Africa, many small towns and rural areas have stagnated, while the more urban locations have continued to reinforce their economic superiority (John, 2012).

Table 6: Reasons for not looking for work and provincial location

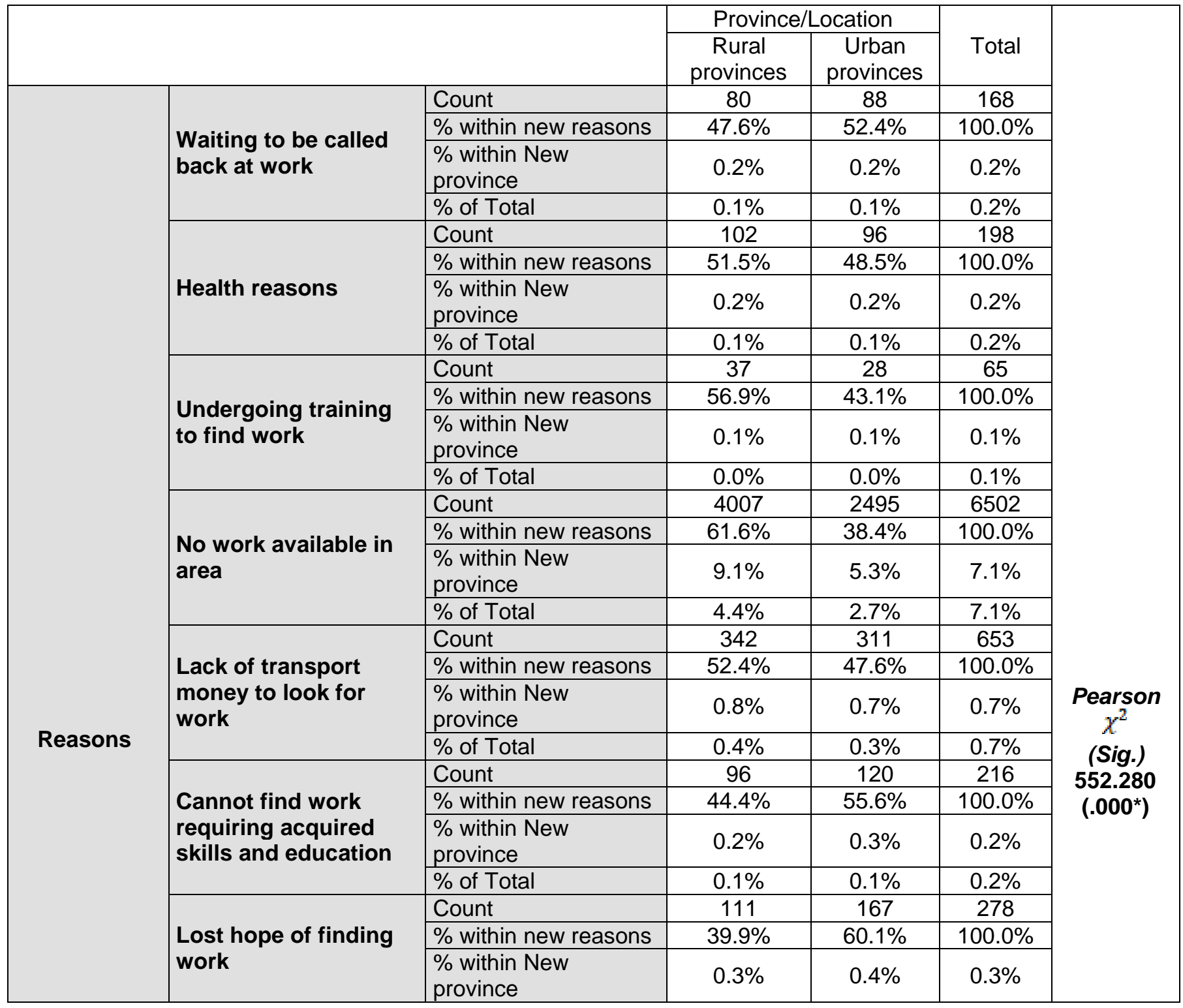

${ }^{1}$ Pearson $\chi^{2}$ (Sig.) $=923.640\left(.000^{\star}\right)$ 


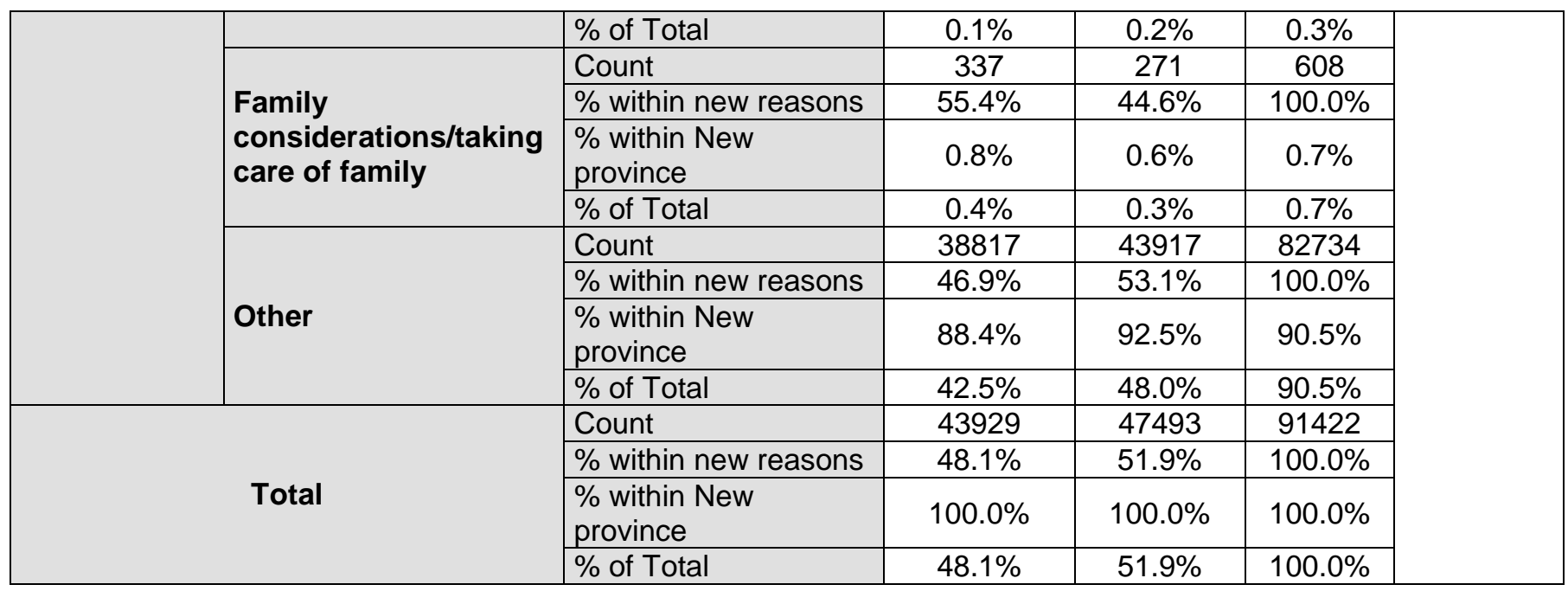

Note: * denotes 0.01 level of significance, ${ }^{* *} 0.05$ level of significance

Source: LMF survey data

Table 7 below further reinforces that young people who have stopped looking for work for various reasons are discouraged job-seekers, who endure lengthier unemployment spells and low probabilities of re-entering the labour market, ultimately trapped in a vicious cycle of poverty. The Pearson $\chi^{2}$ test confirms the differences in the reasons for not looking for work between the various employment statuses in the data.

Table 7: Reasons for not looking for work and employment status

\begin{tabular}{|c|c|c|c|c|c|c|c|c|}
\hline & \multicolumn{4}{|c|}{ Employment status } & \multirow[b]{2}{*}{ Total } & \\
\hline & & & Employed & Unemployed & $\begin{array}{l}\text { Discouraged } \\
\text { job seeker }\end{array}$ & $\begin{array}{l}\text { Other } \\
\text { NEA }\end{array}$ & & \\
\hline & Waiting to & Count & 0 & 0 & 0 & 168 & 168 & \\
\hline & $\begin{array}{l}\text { be called } \\
\text { back at }\end{array}$ & $\begin{array}{l}\text { \% within new } \\
\text { reasons }\end{array}$ & $0.0 \%$ & $0.0 \%$ & $0.0 \%$ & $\begin{array}{r}100.0 \\
\%\end{array}$ & $100.0 \%$ & \\
\hline & & $\begin{array}{l}\text { \% within } \\
\text { Employment } \\
\text { status }\end{array}$ & $0.0 \%$ & $0.0 \%$ & $0.0 \%$ & $0.4 \%$ & $0.2 \%$ & \\
\hline & & $\%$ of Total & $0.0 \%$ & $0.0 \%$ & $0.0 \%$ & $0.2 \%$ & $0.2 \%$ & \\
\hline & Health & Count & 0 & 0 & 0 & 198 & 198 & \\
\hline & reasons & $\begin{array}{l}\text { \% within new } \\
\text { reasons }\end{array}$ & $0.0 \%$ & $0.0 \%$ & $0.0 \%$ & $\begin{array}{r}100.0 \\
\%\end{array}$ & $100.0 \%$ & \\
\hline Reasons & & $\begin{array}{l}\text { \% within } \\
\text { Employment } \\
\text { status }\end{array}$ & $0.0 \%$ & $0.0 \%$ & $0.0 \%$ & $0.5 \%$ & $0.2 \%$ & \\
\hline & & $\%$ of Total & $0.0 \%$ & $0.0 \%$ & $0.0 \%$ & $0.2 \%$ & $0.2 \%$ & \\
\hline & Undergoing & Count & 0 & 0 & 0 & 65 & 65 & \\
\hline & $\begin{array}{l}\text { training to } \\
\text { find work }\end{array}$ & $\begin{array}{l}\text { \% within new } \\
\text { reasons }\end{array}$ & $0.0 \%$ & $0.0 \%$ & $0.0 \%$ & $\begin{array}{r}100.0 \\
\% \\
\end{array}$ & $100.0 \%$ & $\begin{array}{c}\text { Pearson } \\
\chi^{2}\end{array}$ \\
\hline & & $\begin{array}{l}\text { \% within } \\
\text { Employment } \\
\text { status }\end{array}$ & $0.0 \%$ & $0.0 \%$ & $0.0 \%$ & $0.2 \%$ & $0.1 \%$ & $\begin{array}{c}\text { (Sig.) } \\
93594.55\end{array}$ \\
\hline & & $\%$ of Total & $0.0 \%$ & $0.0 \%$ & $0.0 \%$ & $0.1 \%$ & $0.1 \%$ & 5 \\
\hline & No work & Count & 0 & 0 & 6500 & 2 & 6502 & $\left(.000^{\star}\right)$ \\
\hline
\end{tabular}




\begin{tabular}{|c|c|c|c|c|c|c|}
\hline \multirow[t]{3}{*}{$\begin{array}{l}\text { available in } \\
\text { area }\end{array}$} & $\begin{array}{l}\text { \% within new } \\
\text { reasons }\end{array}$ & $0.0 \%$ & $0.0 \%$ & $100.0 \%$ & $0.0 \%$ & $100.0 \%$ \\
\hline & $\begin{array}{l}\text { \% within } \\
\text { Employment } \\
\text { status }\end{array}$ & $0.0 \%$ & $0.0 \%$ & $92.9 \%$ & $0.0 \%$ & $7.1 \%$ \\
\hline & $\%$ of Total & $0.0 \%$ & $0.0 \%$ & $7.1 \%$ & $0.0 \%$ & $7.1 \%$ \\
\hline \multirow{4}{*}{$\begin{array}{l}\text { Lack of } \\
\text { transport } \\
\text { money to } \\
\text { look for } \\
\text { work }\end{array}$} & Count & 0 & 0 & 0 & 653 & 653 \\
\hline & $\begin{array}{l}\text { \% within new } \\
\text { reasons }\end{array}$ & $0.0 \%$ & $0.0 \%$ & $0.0 \%$ & $\begin{array}{r}100.0 \\
\%\end{array}$ & $100.0 \%$ \\
\hline & $\begin{array}{l}\text { \% within } \\
\text { Employment } \\
\text { status }\end{array}$ & $0.0 \%$ & $0.0 \%$ & $0.0 \%$ & $1.7 \%$ & $0.7 \%$ \\
\hline & $\%$ of Total & $0.0 \%$ & $0.0 \%$ & $0.0 \%$ & $0.7 \%$ & $0.7 \%$ \\
\hline \multirow{4}{*}{$\begin{array}{l}\text { Cannot find } \\
\text { work } \\
\text { requiring } \\
\text { acquired } \\
\text { skills and } \\
\text { education }\end{array}$} & Count & 0 & 0 & 216 & 0 & 216 \\
\hline & $\begin{array}{l}\text { \% within new } \\
\text { reasons }\end{array}$ & $0.0 \%$ & $0.0 \%$ & $100.0 \%$ & $0.0 \%$ & $100.0 \%$ \\
\hline & $\begin{array}{l}\text { \% within } \\
\text { Employment } \\
\text { status }\end{array}$ & $0.0 \%$ & $0.0 \%$ & $3.1 \%$ & $0.0 \%$ & $0.2 \%$ \\
\hline & $\%$ of Total & $0.0 \%$ & $0.0 \%$ & $0.2 \%$ & $0.0 \%$ & $0.2 \%$ \\
\hline \multirow{4}{*}{$\begin{array}{l}\text { Lost hope } \\
\text { of finding } \\
\text { work }\end{array}$} & Count & 0 & 0 & 278 & 0 & 278 \\
\hline & $\begin{array}{l}\text { \% within new } \\
\text { reasons }\end{array}$ & $0.0 \%$ & $0.0 \%$ & $100.0 \%$ & $0.0 \%$ & $100.0 \%$ \\
\hline & $\begin{array}{l}\text { \% within } \\
\text { Employment } \\
\text { status }\end{array}$ & $0.0 \%$ & $0.0 \%$ & $4.0 \%$ & $0.0 \%$ & $0.3 \%$ \\
\hline & $\%$ of Total & $0.0 \%$ & $0.0 \%$ & $0.3 \%$ & $0.0 \%$ & $0.3 \%$ \\
\hline \multirow{4}{*}{$\begin{array}{l}\text { Family } \\
\text { considerati } \\
\text { ons/taking } \\
\text { care of } \\
\text { family }\end{array}$} & Count & 0 & 0 & 0 & 608 & 608 \\
\hline & $\begin{array}{l}\text { \% within new } \\
\text { reasons }\end{array}$ & $0.0 \%$ & $0.0 \%$ & $0.0 \%$ & $\begin{array}{r}100.0 \\
\%\end{array}$ & $100.0 \%$ \\
\hline & $\begin{array}{l}\text { \% within } \\
\text { Employment } \\
\text { status }\end{array}$ & $0.0 \%$ & $0.0 \%$ & $0.0 \%$ & $1.6 \%$ & $0.7 \%$ \\
\hline & $\%$ of Total & $0.0 \%$ & $0.0 \%$ & $0.0 \%$ & $0.7 \%$ & $0.7 \%$ \\
\hline \multirow{4}{*}{$\begin{array}{l}\text { Other } \\
\text { reasons }\end{array}$} & Count & 27493 & 18155 & 0 & 37086 & 82734 \\
\hline & $\begin{array}{l}\text { \% within new } \\
\text { reasons }\end{array}$ & $33.2 \%$ & $21.9 \%$ & $0.0 \%$ & $44.8 \%$ & $100.0 \%$ \\
\hline & $\begin{array}{l}\text { \% within } \\
\text { Employment } \\
\text { status }\end{array}$ & $100.0 \%$ & $100.0 \%$ & $0.0 \%$ & $95.6 \%$ & $90.5 \%$ \\
\hline & $\%$ of Total & $30.1 \%$ & $19.9 \%$ & $0.0 \%$ & $40.6 \%$ & $90.5 \%$ \\
\hline \multirow{4}{*}{ Total } & Count & 27493 & 18155 & 6994 & 38780 & 91422 \\
\hline & $\begin{array}{l}\text { \% within new } \\
\text { reasons }\end{array}$ & $30.1 \%$ & $19.9 \%$ & $7.7 \%$ & $42.4 \%$ & $100.0 \%$ \\
\hline & $\begin{array}{l}\text { \% within } \\
\text { Employment } \\
\text { status }\end{array}$ & $100.0 \%$ & $100.0 \%$ & $100.0 \%$ & $\begin{array}{r}100.0 \\
\%\end{array}$ & $100.0 \%$ \\
\hline & $\%$ of Total & $30.1 \%$ & $19.9 \%$ & $7.7 \%$ & $42.4 \%$ & $100.0 \%$ \\
\hline
\end{tabular}

Note: * denotes 0.01 level of significance, ${ }^{* *} 0.05$ level of significance 
Source: LMF survey data

\section{Conclusions and recommendations}

The study in question investigated the youth's perceptions of why they are not looking for work. Of the conjectured reasons, many young people had stopped searching for work mainly because there is a lack of jobs in their areas of location, and this was especially the case for those in rural (non-metropolitan) areas. Another reason that raises concern include a lack of financial resources like transport money which seem to prevent many young people from pursuing employment search. Furthermore, many young job-seekers that have stopped looking for work seem to have education that is not sought by the modern economy, and therefore employers. This was the case for those who have secondary schooling and tertiary education, perhaps suggesting that tertiary graduates could be in fields that are irrelevant to the labour market needs. Lastly, young people in the survey have lost any hope of finding any work, which is an indication of long-term unemployment. From this analysis, it is evident that a low levels of education and a weak economic environment are one of the main challenges that the South African government needs to address the youth unemployment and poverty situation.

The study therefore concludes these factors as the main reasons which authorities need to be aware of. In terms of recommendations, there is need to up-skill ill-educated young work-seekers to better their chances of finding sustainable employment. Poor quality education has seen many youth ending their education before reaching matric, fuelling the unemployment numbers. Therefore, it is crucial that authorities reform the education policy to ensure optimally constructed skills development. Also, more reforms are needed to facilitate an environment conducive to economic growth and investment spending. An implementation of skills training programmes and internships that will ingest a significant number the youth in employment opportunities. The findings of the study prove the necessity to create conditions for sustainable employment opportunities, which will be augmented by a growing economy.

\section{References}

Adcorp. 2014. Jobs in the informal and temporary sectors increase towards the end of 2013. http://www.adcorp.co.za/NEws/Pages/Jobsintheinformalandtemporarysectorsincreasetowar dstheendof2013.aspx Date of access: 06/06/2019

Altbeker A. \& Storme, E. 2013. Graduate Unemployment in South Africa: A Much Exaggerated Problem. Johannesburg: Centre for Development and Enterprise.

Altman, M. 2007. Youth labour market challenges in South Africa. Human Sciences Research Council (HSRC). 
and what interventions help? A Systematic Overview of the Evidence and a Theory of Chang https://www.uj.ac.za/faculties/humanities/csda/Documents/Youth\%20Unemployment\%20ex ec\%20summary\%20FINAL\%20interactive.pdf Date of access: 16 Jul. 2019.

ANNALS of the American Academy of Political and Social Science, 652, 20-47. https://doi.

Axelrad, H., Malul, M. \& Luski, I. 2018. Unemployment among younger and older individuals: does conventional data about unemployment tell us the whole story? Journal for Labour Market Research, 52(3): 1-12.

Barth, M.C., 2000. An aging workforce in an increasingly global world. Journal of Aging and Social Policy, 11(2-3):83-88.

Bernstein, A. (2014). South Africa's key challenges: tough choices and new directions. The ANNALS of the American Academy of Political and Social Science, 652:20-47.

Biavaschi, C., Eichhorst, W. \& Giulietti, G. 2013. Youth Unemployment and Vocational Training. Background Paper for The World Development Report.

Björklund, A. 1985. Unemployment and Mental Health: Some Evidence from Panel Data. The Journal of Human Resources, 20(4):469-483.

Branson, N., De Lannoy, A. \& Brynde, K. 2019. Review of Youth Labour Market Research. Cape Town: SALDRU, University of Cape Town.

Brunner, K. \& Meltzer, A.H. 1978. The Theory of Employment and Unemployment. https://pdfs.semanticscholar.org/7e95/31489733438a37d14d3fbb375e97abf73df8.pdf Date of access: 20 Jul. 2019.

Caliendo, M. \& Schmidl, R. 2015. Youth Unemployment and Active Labor Market Policies in Europe. IZA Discussion Paper No. 9488, Germany.

Cheung, C., Kam, P.K. \& Ngan, M.R. 2011. Age discrimination in the labour market from the perspectives of employers and older workers. International Social Work, 54(1): 118-136.

Cloet, A. 2015. Youth unemployment in South Africa A theological reflection through the lens of human dignity. Missionalia, 43(3): 513-525).

De Jongh, J., Mncayi, P. \& Mdluli, P. 2019. Analysing the impact of water access and sanitation on local economic development (LED) in the Sedibeng District Municipality, South Africa. International Journal of Innovation, Creativity and Change, 5(2).

De Jongh, JJ. 2017. Youth employment barriers in the Emfuleni and Metsimaholo local municipal areas. Vanderbijlpark: North-West University. (Dissertation - Mcom).

De Lannoy, A., Graham, L., Patel, L. \& Leibbrandt, M. (2018). What drives youth unemployment and what interventions help? A systematic overview of evidence and a theory of change. High-level overview report. Cape Town: REDI 3×3, University of Cape Town.

de Witte, H. Rothmann, S. \& Jackson, L.T.B. 2012. The psychological consequences of unemployment in South Africa. South African Journal of Economics and Management Sciences (Sajems), 15(3): 235-252.

Department of Higher Education and Training (DHET). 2019. Statistics on Post-School Education and Training in South Africa: 2017. Pretoria, Government Printer. 
Dolado, J.J. 2015. Introduction. (In Dolado, J.J., ed. No country for young people: youth labour market problems in Europe. London. Centre for Economic Policy Research. p.1-14).

Eriksson, S. \& Dan-Olof, R. 2014. Do Employers Use Unemployment as a Sorting Criterion When Hiring? Evidence from a Field Experiment. American Economic Review, 104(3):1014-39.

Farré, F., Fasani, F. \& Mueller, H. 2015. Feeling Useless: The Effect of Unemployment on Mental Health in the Great Recession. Barcelona GSE Working Paper Series Working Paper 838.

Festus, L., Kasongo, A., Moses, M. \& Yuc, d. 2016. The South African labour market, 1995-2015. Development Southern Africa, 33(5):579-599.

Fischer, J. \& Siddiq, F. 2013. Trends in Metropolitan and Non-Metropolitan Populations in Canada and the United States over Fifty Years.

https://www.wilsoncenter.org/sites/default/files/Int_Journal_URR.pdf Date of access: 09/09/2019.

Flek, M., Hala, M. \& Mysíková, M. 2017. How different are youth and adult labour market transitions? https://style-handbook.eu/contents-list/skills-and-education-mismatch/howdifferent-are-youth-and-adult-labour-market-transitions/ Date of access: 20/07/ 2019.

Furnham, A. 1984. Unemployment, attribution theory, and mental health: a review of the British literature. International Journal of Mental Health, 13(1/2): 51-67.

Graham, L., Lannoy, A.D., Patel, L. \& Leibbrandt, M. 2018. What drives youth unemployment

Green, F. \& Henseke, G. 2016. Should governments of OECD countries worry about graduate underemployment? Oxford Review of Economic Policy, 32(4): 514-537

Haffejee, F., O'Connor, L. \& Govender, N. 2017. Factors associated with unintended pregnancy among women attending a public health facility in KwaZulu-Natal, South Africa. South African Family Practice, 1(1):1-5.

ILO (International Labour Organisation). 2010. Global employment trends for youth. International Labour Office. Geneva.

ILO (International Labour Organisation). 2018. World Employment Social Outlook. International Labour Office. Geneva.

Ingle, K., Mlatsheni, C. 2017. The extent of churn in the South African youth labour market: Evidence from NIDS 2008-2015. Working Paper Number 201. Cape Town: University of Cape Town.

Jacob, A. 2008. Unemployment benefits and parental resources: what helps the young unemployed with labour market integration? Journal of Youth Studies, 11(2): 147-163.

Jahoda, Marie. 1982. Employment and Unemployment: A Social-Psychological Analysis. New York: Cambridge University Press.

John, A. 2012. Secondary cities in South Africa: the start of a conversation. South African Cities Network.

Kelly, E., McGuinness, S., O'Connell, J.P. 2012. Transitions to long-term unemployment risk among young people: evidence from Ireland. Journal of Youth Studies, 15(6):780-801.

Kooreman, P. \& Ridder, G. 1983. The effects of age and unemployment percentage on the duration of unemployment. European Economic Review, 20:41-57. 
Kumo, W. L., Chulu, O. \& Minsat, A. 2016. African economic outlook: South Africa, 2016. New York, NY: United Nations Development Programme.

Lannoy, A.D., Graham, L., Patel, L. \& Leibbrandt, M. 2018. A Systematic Overview of the Evidence and a Theory of Change High-level Overview Report.

Makiwane, M. \& Kwizera, S. 2008. Youth and Well-Being: A South African Case Study. Soc Indic Res, 91:223-242.

Mathe, T. 2019. SA's GDP slumps to its lowest in a decade. Mail \& Guardian, 4 Jan. https://mg.co.za/article/2019-06-04-sas-gdp-slumps-to-its-lowest-in-a-decade Date of access: 10/09/2019

Mlatsheni, C, 2007. A survey of youth labour market trends. Draft paper prepared for Human Sciences Research Council.

Mlatsheni, C. \& Ranchhod, V. 2017. Youth labour market dynamics in South Africa: evidence from NIDS 1-2-3. Working paper 39. Cape Town: University of Cape Town.

Mlatsheni, C. 2014. Youth unemployment and the transition from school to work in Cape Town. Cape Town: University of Cape Town. (Thesis - PhD).

Mncayi, P. \& De Jongh. 2019. An analysis on the antecedents of young employees'earning potential in South Africa. Forthcoming.

Mncayi, P. \& Dunga, S.H. 2016. Career choice and unemployment length: A study of graduates from a South African university. Industry and Higher Education, 30(6):413-423.

Moleke, P. 2010. The graduate labour market. In: M. Letseka, M. Cosser, M. Breier \& M. Visser. (Eds.), Student Retention \& Graduate Destination: Higher Education \& Labour Market Access \& Success. (pp. 87-95). Cape Town: HSRC Press.

National Planning Commission. 2011. Economy Diagnostic. Pretoria: National Planning Commission.

Neumark, D. \& Stock, W.A.1997. Age discrimination laws and labour market efficiency. National Bureau of Economic Research Working Paper 6088, Cambridge.

Nonyana, J.Z \& Njuho, P.M. 2018. Modelling the length of time spent in an unemployment state in South Africa. S Afr J Sci. 2018;114(11/12), Art.

Oluwajodu F, Blaauw D, Greyling L, et al. (2015) Graduate unemployment in South Africa: perspectives from the banking sector. SA Journal of Human Resource Management 13(1): $1-9$.

Orr, L. \& Van Meelis, T. 2014. Women and gender relations in the South African labour market: a twenty-year review. Woodstock: Labour Research Service.

Patel, L., Khan, Z. \& Englert, T. 2018. How might a national minimum wage affect the employment of youth in South Africa? Development Southern Africa. Development Southern Africa. Johannesburg: University of Johannesburg.

Pauw, K., Oosthuizen, M. \& van der Westhuizen, C. 2006. Graduate Unemployment in the Face of Skills Shortages: A Labour Market Paradox. DPRU Working Paper 06/114. Cape Town: University of Cape Town. 
Rankin, NA \& Roberts, G, 2011. Youth unemployment, firm size and reservation wages in South Africa. South African Journal of Economics 79(2):128-45.

SAIRR (2016) NGS: National Growth Strategy - Investment, Infrastructure, Employment and Empowerment. Johannesburg: South African Institute of Race Relations. Available at: http://irr.org.za/reports-and-publications/occasionalreports/files/sairr_national-growthstategy_web_200516.pdf Date of access: 09/09/2019

Schwartz, D.A. \& Kleiner, B.H. 1999. The relationship between age and employment opportunities. Equal Opportunities International, 18(5/6):105-110.

Smith, J-M, 2011. Connecting Youth South Africans to Opportunity. Literature Review and Strategy. www.dgmt.co.za/files/2011/05/Literature-Review-Strategy.pdf Date of access:16/09/2019.

Spaull N (2013) South Africa's Education Crisis: The Quality of Education in South Africa 19942011. Johannesburg: Centre for Development and Enterprise.

Stats SA (Statistics South Africa). 2018. Quarterly Labour Force Survey. Pretoria.

Stats SA (Statistics South Africa). 2019. Quarterly Labour Force Survey. Pretoria.

Steadman, K. \& Taskila, T. 2015. Symptoms of depression and their effects on employment. The Work Foundation, London.

Strandh, M., Winefield, A., Nilsson, K. \& Hammarstro, A. 2014. Unemployment and mental health scarring during the life course. European Journal of Public Health, 24(3):440-445.

Taris, W.T. 2002. Unemployment and Mental Health: A Longitudinal Perspective. International Journal of Stress Management, 9(1): 43-57.

Taylor, P. \& Walker, A. 2003. Age Discrimination in the Labour Market and Policy Responses: The Situation in the United Kingdom. The Geneva Papers on Risk and Insurance, 28(4):612-624.

The South African Depression and Anxiety Group. 2019. The link between unemployment and depression. http://www.sadag.org/index.php?option=com_content\&view=article\&id=385:the link-between-unemployment-and-depression\&catid=69\&ltemid=132 Date of access: 16/09/2019.

Van Broekhuizen H. 2016.Graduate unemployment and higher education institutions in South Africa. Bureau for Economic Research and Stellenbosch Economic. Working Paper 08/16. South Africa: University of Stellenbosch.

van de Rheed, T.J. 2012. Graduate unemployment in South Africa: Extent, nature and causes. MCom- University of the Western Cape.

Weingarden, A, 2017. Labor Market Outcomes in Metropolitan and Non-Metropolitan Areas:

Signs of Growing Disparities," FEDS Notes. Washington: Board of Governors of the Federal Reserve System, September 25, 2017, https://doi.org/10.17016/2380-7172.2063.

youth in South Africa. Southern Africa Labour and Development Research Unit, University of Cape Town. 
Zoch, A. 2015. Life chances and class: estimating inequality of opportunity for children and adolescents in South Africa. Development Southern Africa, 32, 57-75. https://doi.org/10.10 80/0376835X.2014.965386_Date of access: 09/09/2019. 